\title{
Nankyoku no kyoku: The cultural life of the Shirase Antarctic Expedition 1910-12
}

\author{
Rupert Summerson ${ }^{1}$
}

\section{Introduction}

The austral summer of 2011-12 was the centenary of many significant milestones in Antarctic history: Amundsen's successful expedition to reach the South Pole, Scott's tragic demise, the arrival of Mawson's expedition in the Antarctic, and not the least is the only just remembered Japanese expedition to Antarctica under the leadership of Lieutenant Nobu Shirase. ${ }^{2}$

The Japanese Antarctic Expedition (1910-13) was a Japanese private expedition organised by Lieutenant Nobu Shirase and funded largely by donations. Like many of the other major expeditions of the so-called Heroic Era, it was only partially funded by the government. Until very recently, little was known about the expedition in the English-speaking world; apart from a handful of articles in journals and magazines and summaries derived from these same articles in general books about the Antarctic, there is very little detail. Until the publication in late 2011 of the long awaited translation of Nankyoku-ki, the official account of the expedition by the Shirase Expedition Supporters' Association, there was very little information about the expedition in English, the main source of information being Ivor Hamre (1933). ${ }^{3}$ RA Swan contributed a short article 22 years later. ${ }^{4}$ The Reader's Digest book on Antarctica included a section on the expedition, which seemed to be based largely on Hamre's article. ${ }^{5}$ There is, of course, substantially more information in Japanese, though accessing this from Australia is very difficult. The bibliography of the expedition compiled by Chet Ross, which principally comprises sources in Japanese, is invaluable

\footnotetext{
1 Dr Rupert Summerson, PO Box 3853, Manuka, ACT 2603, rupert.summerson@bigpond.com.

2 In Japanese, people's names are given with the family name first, then given name. When translating names into English I have made the name order the same as in English, i.e. given name followed by family name.

3 Shirase Antarctic Expedition Supporters' Association, ed. (2011) The Japanese South Polar Expedition 1910-12: a record of Antarctica. Erskine Press and Bluntisham Books, Norwich; Ivar Hamre (1933) 'The Japanese South Polar Expedition of 1911-1912: a little-known episode in Antarctic exploration'. Geographical Journal 82: 411-23.

4 RA Swan (1955) 'Forgotten Antarctic venture: the first Japanese south polar expedition 1911-1912'. Walkabout 21 (August): 31-33.

5 Reader's Digest (1990) Antarctica: great stories from the frozen continent. Reader's Digest, Sydney.
} 
in understanding what had been written about the expedition and some initial details about the cultural life of the expedition. ${ }^{6}$ My correspondence with him led to some fruitful discoveries. Two recent $\mathrm{PhD}$ theses about the Shirase expedition, McInnnes (2009) $)^{7}$ and Stevenson (2010), ${ }^{8}$ have become available to the general reader.

\section{Main events of the expedition}

The expedition left Tokyo on 1 December 1910. The ship, the Kainan Maru ('Southern Pioneer'), was a 204-ton, $30.5 \mathrm{~m}$ long, three-mast auxiliary schooner that had once been a fisheries supply vessel. Its captain was Naokichi Nomura, who was an experienced sailor. The first port of call was Wellington in New Zealand, which they reached on 7 February 1911. They departed Wellington on 11 February, heading south towards Antarctica, encountering ice near Cape Adare. It was already March and too late in the season to attempt to enter the Ross Sea. The ship therefore turned north and arrived in Sydney on 1 May 1911. There was considerable disappointment among expedition members about this setback but the expedition resolved to return to Antarctica the following summer. The expedition spent the winter at Parsley Bay, near Watson's Bay in Sydney, while the Kainan Maru was overhauled at Jubilee Dock in Sydney. Shirase despatched Keiichi Tada, the secretary of the expedition, and Captain Nomura back to Japan in May 1911 to raise funds and bring more dogs. Nomura returned in October 1911 with provisions and spare parts for the ship and Tada returned in November bringing 29 sledge dogs. On 19 November 1911 the expedition departed Sydney en route to Antarctica. The first iceberg was encountered on 11 December and they entered the pack ice the following day. They crossed the Antarctic Circle on 21 December at longitude $177^{\circ} \mathrm{E}$ (near Scott Island at the entrance to the Ross Sea). On 29 December they emerged from the pack ice into open water in the Ross Sea.

On New Year's Day 1912, an important day in the Japanese calendar, they were at $69^{\circ} 40^{\prime} \mathrm{S}$. The mountains of the Admiralty Range, South Victoria Land, the first land they had sighted, came into view on 3 January 1912. Cape Adare was also sighted but they were unable to land there. On 4 January Coulman Island came into view and from there they steamed south-eastwards until the Great Ice Barrier, which is now called the ice front of the Ross Ice Shelf, came into view

\footnotetext{
6 Chet Ross (2010) Lieutenant Nobu Shirase and the Japanese Antarctic Expedition of 1910-1912: a bibliography. Adélie Books, Santa Monica CA.

7 Brendan Neil McInnes (2009) The forgetting of a hero: the Antarctic explorer Shirase Nobu. University of New England, Armidale, NSW.

8 William R Stevenson III (2010) The spirit of adventure: Japanese exploration and the quest for the South Pole. University of Hawai'i, Manoa.
} 
on 10 January at latitude $78^{\circ} 10^{\prime} \mathrm{S}$. They then continued sailing eastwards along the ice front, reaching their initial destination, the Bay of Whales, on 15 January 1912. The main landing party went ashore the following day and established a base camp. The five members of the 'Dash Patrol', including Shirase and Takeda, the chief scientist, departed from the base camp on 20 January taking two dog sledges. On 28 January the Dash Patrol reached their furthest point south at $80^{\circ} 05^{\prime} \mathrm{S}$ and from there they returned safely to base camp, arriving on 31 January. Meanwhile the Kainan Maru sailed eastwards and dropped two landing parties on 23 January to explore the Alexandra Mountains in Edward VII Land. Unfortunately they were not able to reach the summit or even the exposed rock because of a wide bergschrund below the outcrop. ${ }^{9}$ Both parties safely returned to the ship on 24 January. The ship then continued eastwards to attempt to exceed Captain Scott's furthest east point during the Discovery expedition in 1902. The Kainan Maru reached $152^{\circ} \mathrm{W}$ on 26 January, $17.3 \mathrm{~km}$ further east than Discovery's record. The ship was then turned round and headed back to the Bay of Whales to retrieve the main landing party.

On 3 February 1912 the ship was manoeuvred into place against the sea ice near a low point in the ice cliffs and by 10 am on 4 February most of the supplies and equipment had been loaded back onto the ship. The weather started to deteriorate rapidly and the men and six of the dogs managed to get back on board as the bay became ice-bound with an onshore wind. The ship made a narrow escape but 20 dogs were left behind. Shirase had hoped to make a final landing on Coulman Island but the bad weather continued and on 14 February a conference was held at which it was decided that enough of the aims of the expedition had been achieved, so the order was given to set course for New Zealand. The ship arrived in Wellington on 23 March. Shirase, Takeda and three others left the ship in Wellington to head home by mail steamer to make a report and make arrangements for the expedition's return. The Kainan Maru with the rest of the expedition finally arrived at Tokyo to a rapturous welcome on 20 June 1912.

\section{Music on the Japanese Antarctic Expedition}

Most if not all of the expeditions of the heroic era had some form of musical life:

A gramophone with a large supply of records was, I think, our best friend. Of musical instruments we had a piano, a violin, a flute, mandolins, not forgetting a mouth-organ and an accordion. All the publishers had been kind enough to send us music, so that we could cultivate this art as much as we wished. ${ }^{10}$

9 A bergschrund is a permanent crevasse formed on mountain slopes in glacierised terrains by the moving ice pulling away from the fixed ice attached to the rock.

10 Roald Amundsen (1912) The South Pole. John Murray, London. 
Meares has become enamoured of the gramophone. We find we have a splendid selection of records. The pianola is being brought in sections, but I'm not at all sure it will be worth the trouble. ${ }^{11}$

Sunday being quiet Scott read service while the officers and men grouped round the wheel. We seldom had service on deck; for Sundays became proverbial days for a blow on the way out, and service, if held at all, was generally in the ward-room. On one famous occasion we tried to play the pianola to accompany the hymns, but, since the rolls were scored rather for musical effect than for church services, the pianola was suddenly found to be playing something quite different from what was being sung. All through the expedition the want of someone who could play the piano was felt, and such a man is certainly a great asset in a life so far removed from all the pleasures of civilization. As Scott wrote in The Voyage of the Discovery, where one of the officers used to play each evening: 'This hour of music has become an institution which none of us would willingly forgo. I don't know what thoughts it brings to others, though I can readily guess; but of such things one does not care to write. I can well believe, however, that our music smoothes over many a ruffle and brings us to dinner each night in that excellent humour, where all seem good-tempered, though "cleared for action" and ready for fresh argument.' ${ }^{12}$

During the afternoon three Adélie penguins approached the ship across the floe while Hussey was discoursing sweet music on the banjo. The solemn-looking little birds appeared to appreciate 'It's a Long Way to Tipperary', but they fled in horror when Hussey treated them to a little of the music that comes from Scotland. The shouts of laughter from the ship added to their dismay, and they made off as fast as their short legs would carry them. ${ }^{13}$

The gramophone is wound and the record goes on. It is a band piece, beginning quietly, but accelerating to a stirring crescendo, in which the loud clash of cymbals comes faster and faster, to reach the climax in a resounding crash. Then the music dies away in a soothing melody. It is Mertz's favourite record, and peculiarly adapted to his personality. Long since it has become known as 'Mertz killing seals', and is very suggestive of his emphatic methods. ${ }^{14}$

11 RF Scott (1913) Scott's last expedition. John Murray, London.

12 Apsley Cherry-Garrard (1922) The worst journey in the world. Constable \& Co Ltd, London.

13 Ernest Shackleton (1919) South: the story of Shackleton's 1914-1917 expedition. Heinemann, London.

14 Charles Francis Laseron (1947) South with Mawson: reminiscences of the Australasian Antarctic Expedition, 1911-1914. Australasian Publishing Co Pty Ltd, Sydney. 
At the outset, it was hard to believe that the Shirase Antarctic expedition would be any different. The publication of a bibliography of the Shirase expedition was the stimulus for an investigation into whether the Japanese Antarctic expedition included some music. ${ }^{15}$ Following some correspondence with the compiler of the bibliography, Chet Ross, I asked whether, during the course of his researches, he had encountered any mention of music being played on the expedition. He responded with an illustration from a book called Yamato yukihara: Shirase Nankyoku tanken-tai ('Yamato snow plain in Antarctica: Shirase's expedition story') by Sekiya Toshitaka (Figure 1). This book is the story of the expedition written for children, but Ross reassured me that the author was meticulous in representing the events of the expedition accurately, albeit in a form accessible to children. The illustration shows a scene on the foredeck of the expedition ship, the Kainan Maru, showing the crew lounging on the deck around a figure sitting cross-legged playing a shakuhachi (a Japanese end-blown bamboo flute). Nearby was a wind-up gramophone. No information was forthcoming about the musician, however.

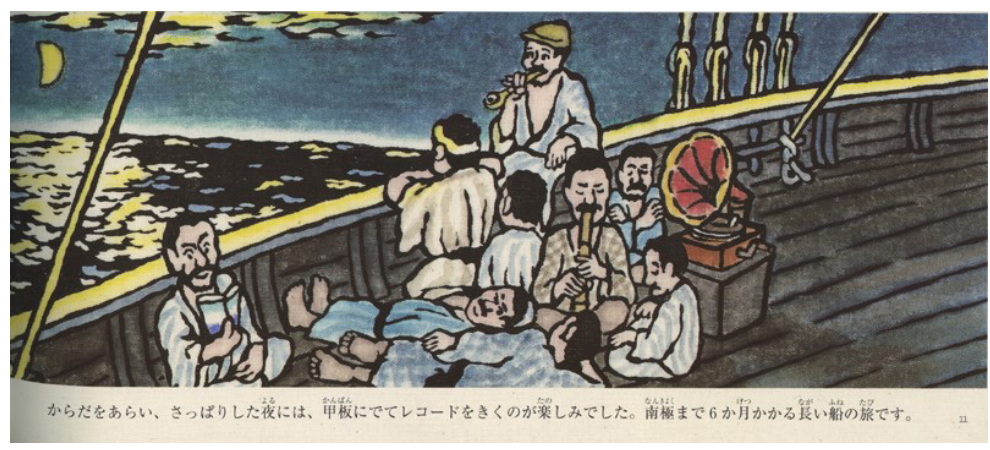

\title{
Figure 1. Illustration from Toshitaka (2002) Yamato yukihara: Shirase Nankyoku tanken-tai. ${ }^{16}$
}

\begin{abstract}
Note: The caption reads: 'We enjoyed sitting on the deck after washing, and listening to the records on fresh nights. It was a very long six months boat journey to Antarctica.' (translation courtesy of Noriko Sakai).

Source: Sekiya Toshitaka and Fukuinkan Shoten Publishers, Tokyo.

Despite the paucity of information about the expedition in English, it has been possible to compile a brief account of the cultural life of the expedition, in particular the music and poetry. The following are extracts from the English translation of Nankyoku-ki, the official record of the expedition. ${ }^{17}$
\end{abstract}

15 Ross (2010) Lieutenant Nobu Shirase and the Japanese Antarctic Expedition of 1910-1912.

16 Sekiya Toshitaka (2002) Yamato yukihara: Shirase Nankyoku tanken-tai. Fukuinkan Shoten, Tokyo.

17 Shirase Antarctic Expedition Supporters' Association (2011) The Japanese South Polar Expedition 1910-12. 
With one last long look and one last goodbye, they parted. Just then the sudden sad note of a shakuhachi trembled across the water, a note to rend the hearts of those we left behind as we set off on our long and lonely voyage. ${ }^{18}$

That evening [20 December 1910] we all went up on deck in search of cooler air. As we stood around chatting and admiring the brightness of the moon the low notes of a shakuhachi rose from some far corner of the ship and played a harmony to the sound of the waves. ${ }^{19}$

29 December 1911. Having made a general survey of the activities on deck, Lt Shirase put Tada and Muramatsu in charge and settled down to enjoy some music on the gramophone. ${ }^{20}$

Kenjo Tsunabuchi's two-volume Kyoku: Shirase Chüi Nankyoku tankenki, about the Shirase expedition, was published in $1983 .{ }^{21}$ Nankyoku (南極) is the Japanese word for Antarctica; its meaning is derived from nan (南), which means south (Kanji/Chinese), and kyoku (極), which means furthest extent or pole. Kyoku also has other meanings, including music (曲), though there is no etymological link between pole and music.

Tsunabuchi's book, which is not in Ross' bibliography, is a historical novel but both McInnes (2009) and Stevenson (2010) agree that it contained much useful information. According to McInnes it is 'a work very firmly based on the historical facts', ${ }^{22}$ and Stevenson says that it 'stands as the farthest reaching and most intriguing account to date'.$^{23}$ First and foremost, it revealed the name of the shakuhachi player on the expedition, Keiichi Tada (多田恵一) (Figure 2).

18 Shirase Antarctic Expedition Supporters' Association (2011) The Japanese South Polar Expedition 1910-12, p. 54 .

19 Shirase Antarctic Expedition Supporters' Association (2011) The Japanese South Polar Expedition 1910-12, p. 59.

20 Shirase Antarctic Expedition Supporters' Association (2011) The Japanese South Polar Expedition 1910-12, p. 112.

21 Kenjō Tsunabuchi (1983) Kyoku: Shirase Chūi Nankyoku tankenki ('Pole: Lt Shirase's Antarctic journey'). Shinchōsha, Tōkyō.

22 McInnes (2009) The forgetting of a hero, p. 51.

23 Stevenson (2010) The spirit of adventure, p. 38. 


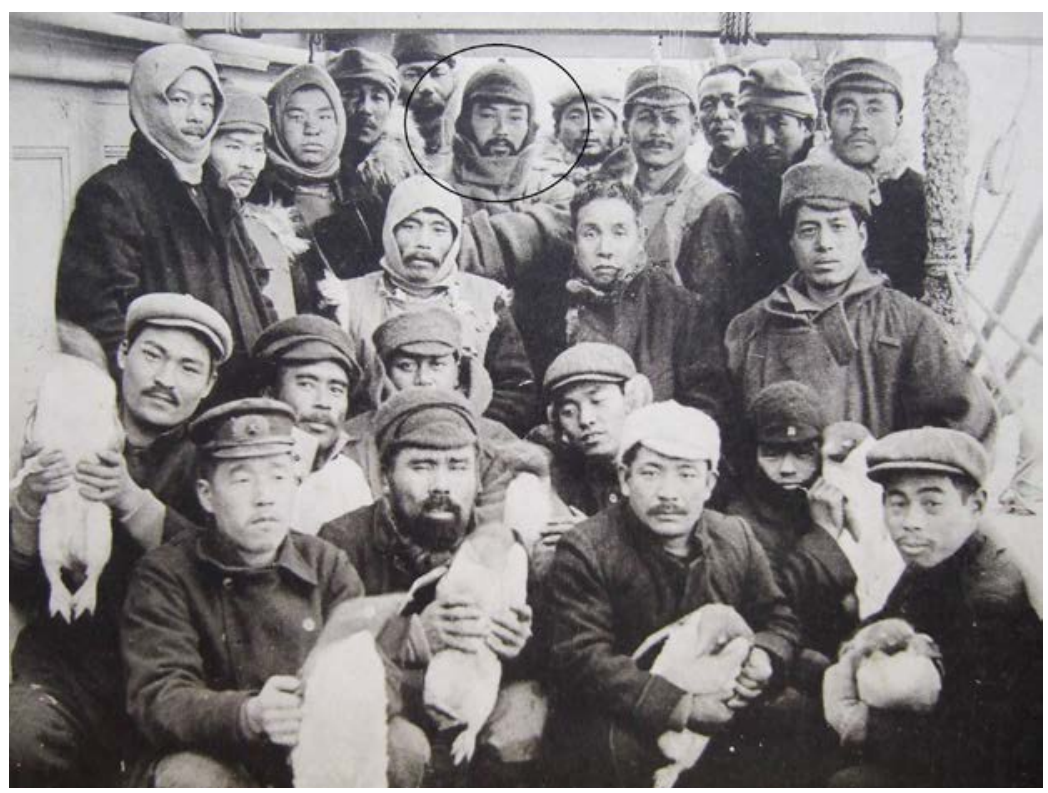

Figure 2. Members of the Japanese Antarctic Expedition on the deck of the Kainan Maru in January 1912. Keiichi Tada is circled in the back row.

Source: Shirase (1913) Nankyoku-ki.

Tada was the first person to be recruited to the expedition and was appointed as secretary, becoming Shirase's right-hand man. ${ }^{24}$ When the expedition returned to Sydney after the failed first attempt to reach Antarctica in 1911, Tada and Captain Nomura returned to Japan to report on the expedition, raise funds for a second attempt and return to Australia with provisions, spare parts for the ship and 26 sledge dogs (the dogs taken on the first voyage had all died, except for one). Tsunabuchi records:

Tada went to Okuma's house with Miura ${ }^{25}$ after dinner and made Miura talk about the life in Sydney. After that, as Okuma asked, Tada played Shakuhachi for Mrs. Okuma and other ladies of high society. Okuma was satisfied with Tada's playing and named that shakuhachi 'kozasa-go' which means little bamboo leaf. Tada wrote 'the moon is clear in the sky tonight, and we had tasteful night' ${ }^{26}$

Tsunabuchi also mentioned that Murakami wanted to send Horiuchi instead of Tada, as Tada's behaviour was not good. But in the end Tada was sent from

24 Ross (2010) Lieutenant Nobu Shirase and the Japanese Antarctic Expedition of 1910-1912, p. 30.

25 There is some confusion about who Miura was and whether Kenjo meant Nomura, the ship's captain who returned to Japan with Tada to obtain more supplies.

26 Tsunabuchi (1983) Kyoku: Shirase Chüi Nankyoku tankenki, translation by Noriko Sakai. 
Yokohama with 29 dogs. Tada fell out with Shirase at some point and was relegated to the position of assistant naturalist during the second summer. Ross suspects that the falling out may have had something to do with Tada writing an article for a magazine in Tokyo, without Shirase's knowledge, when he returned there during the winter in Sydney. ${ }^{27}$ There is very little mention of him in Nankyoku$k i{ }^{28}$ It is notable also that no mention is made of who played the shakuhachi the three times it is mentioned in Nankyoku-ki. Tada left the ship immediately it arrived in Yokohama and took no part in the return celebrations in Tokyo. He wrote four books about the expedition, ${ }^{29}$ two of which were published before Shirase's own account, one and two months respectively after the expeditions return. In 1915 he published his autobiography, ${ }^{30}$ which includes a photograph of him looking very much at ease with Count Okuma. ${ }^{31}$ Late in life he published another book about the Antarctic expedition. ${ }^{32}$

It has not yet been possible to determine what pieces of music Tada played or what was played on the gramophone. Tada's books are now very rare, even in Japan, which, compounded by language difficulties, makes it very difficult to find a copy. There is, however, a glimmer of light into this as yet dark corner of the expedition. Tsunabuchi describes an incident soon after the expedition left Tokyo at the beginning of the expedition. ${ }^{33}$ It was the first time that they had a Japanese-style hot bath since they left Japan. For Japanese people taking a bath is really important so they felt that it was a special occasion. After the bath they enjoyed a nice meal with fresh seafood. Everyone was happy, they listened to some $78 \mathrm{rpm}$ records on the gramophone and started singing songs, including the expedition's song that Tada had composed (see below). Takeda asked Tada to teach him to sing Hakata-bushi (bushi is a common suffix for Japanese folk songs and means something like melody ${ }^{34}$ ), thus Hakata-bushi means melody or song from Hakata). Takeda thought that it was funny as he was from Hakata and Tada was born in China (which was common at that time). That this was a real incident, not one made up by Tsunabuchi, is confirmed in Nankyoku Tanken Nikki (Antarctic Expedition Diary), written by Tada and published in 1912. ${ }^{35}$

Hakata was a trading port on the west coast of Japan on the island of Kyushu in Fukuoka Prefecture. It was absorbed into Fukuoka City in the late 19th century

27 Ross (2010) Lieutenant Nobu Shirase and the Japanese Antarctic Expedition of 1910-1912.

28 Shirase Antarctic Expedition Supporters' Association (2011) The Japanese South Polar Expedition 1910-12.

29 Keiichi Tada (1912a) Nankyoku tanken shiroku ('The authentic account of the Antarctic Expedition').

Keiseisha, Tokyo; (1912b) Nankyoku tanken nikki ('Antarctic expedition diary'). Maekawa Bunoeikaku, Tokyo.

30 Keiichi Tada (1915). Shokon ('The Scar'). Ibuki Shobou, Tokyo.

31 Ross (2010) Lieutenant Nobu Shirase and the Japanese Antarctic Expedition of 1910-1912, p. 35.

32 Keiichi Tada (1958) Nankyoku tanken jitsuroku ('The true record of the Antarctic Expedition'). Kainan

Shuppan Kyokai, Tokyo.

33 Translation by Noriko Sakai.

34 David W Hughes (2008) Traditional folk song in modern Japan. Global Oriental, Folkestone, UK.

35 Tada (1912b) Nankyoku tanken nikki. 
and is now a ward in that city (Wikipedia). There is a strong tradition of folk song ( in $\left.^{\prime} y \bar{o}\right)$ in Japan: Min'yō wa kokoro no furusato ('Folk song is the heart's home town'). ${ }^{36}$ In any one buraku (hamlet) in early modern (Meiji era) times, a community might know more than 100 songs, which might be classified into songs for a number of different events such as festival songs, work songs, party songs, children's songs, etc. Hakata-bushi is a romantic song about a young woman dressed wearing a Hakata obi (the broad sash worn round the waist over the kimono). She walks gracefully, like a willow, and the moon rises over pine

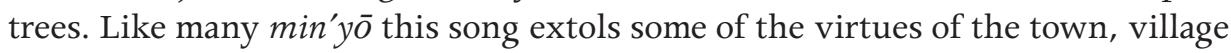
or district in question. It is likely that many, if not most, of the expedition members would have known songs from their home towns and that these would have been sung at various times during the expedition.

\section{Expedition songs}

'Our route took us over the Kaji-bashi (bridge), through the Tatami district, and down Shindoro street ... with the crowd still singing the expedition's song as they went. ${ }^{37}$ The song, composed by Kamiya Fusen, ${ }^{38}$ was sung at the departure of the expedition and at its return. As McInnes notes, the biwa is a traditional Japanese musical instrument, closely related to the Chinese pipa. Its closest Western counterpart is a lute. The title Tanken Biwa Uta ('Expedition Biwa Song') implies that it was composed to be accompanied on the biwa. Given that the biwa is quite a soft instrument, it seems a curious choice for what seems to have been intended as a rousing song for massed voices.

\section{Tanken Biwa Uta ('Expedition Biwa Song')}

With no time for resting on the tiller, they part the waves that reach the sky,

Through the scorching heat that brings the Kuroshio to a boil,

They sail beyond the equator

Relentlessly onwards, on to the south,

Through the frozen seas,

Beneath Mount Erebus, rising 4000 shaku into the sky.

How we anticipate the high spirits of the men as they go ashore,

Carrying the hopes of the Japanese people

To that place yonder where the silent, endless

36 Hughes (2008) Traditional folk song in modern Japan, p. 1.

37 Shirase Antarctic Expedition Supporters' Association (2011) The Japanese South Polar Expedition 1910-12, p. 237.

38 McInnes (2009) The forgetting of a hero, p. 244. 
World of Silver lies.

Men! Crest those waves on your way to the Southern Hemisphere!

On, to the very ends of the Earth, never resting until you reach the Pole! Where you will raise our flag, your sincerity burning for a thousand years!

Not knowing the way, you drag your sledges across the immense icefields through ways uncharted,

Valiantly determined even at risk of life

To overcome the countless hardships and scale the soaring peaks of ice.

At the very point of the Earth's axis,

To the brilliant glow of our Sovereign's majesty,

At the raising of the Hinomaru

Your cheers will rend the skies,

And your shouts of triumph never die.

Truly, a courageous and heroic venture!

Tsunabuchi records a different song, however: Nankyoku Tankentai Taika ('The song of the Antarctic expedition team'), which he infers was written by Tada but may, in fact, have been written by Kenju Ōwada, 'a famed poet and lyricist' ${ }^{39}$

\section{Nankyoku Tankentai Taika ('The song of the Antarctic expedition team')}

So, our destination is the great ice field in the South at the end of the earth's axis.

Our ship is the famous "Kainan" (Southern Explorer), loaded with an important mission.

There is no need to fear the many hardships that may come to us in moving through the ocean.

Many difficulties will come to us as we follow the mountains and rivers, but we need not worry.

Our team bears the hopes of seventy million of our compatriots.

Our team will go forward with the eyes of our country on us.

Let's go bravely and put the sails up in the sunrise.

Let's move forward without looking back, with our sleek dogs in attendance.

(translation by Noriko Sakai)

39 Stevenson (2010) The spirit of adventure, p. 145. 
There are a number of questions about the second song. Again, was it a fictional device by Tsunabuchi? There are so many differences between it and Kamiya Fusen's song that it is not possible to be sure that they are not two translations of the same song. Tsunabuchi was familiar with both Shirase's and Tada's books $^{40}$ so he must have known of Kamiya Fusen's song. Perhaps Tada made up the words, or perhaps misremembered the words from the departure of the expedition. Or perhaps Tada wrote a new song for an as yet unknown reason. Without new information this will have to remain a mystery.

\section{Poetry on the Japanese Antarctic Expedition}

The tradition of poetry writing in Japan extends into the distant past; the publication of the first anthology of poetry, the Manyōshu, was in the 7th century. Poetry has been, and still is, a vital part of Japanese culture. It reached its most highly developed form in the Emperor's court but it was by no means restricted to the court - the Manyōshü includes poems written by people from all walks of life. ${ }^{41}$ It was expected that every warrior would be as skilled with the brush as with the sword. Even that most famous of Japanese swordsmen, Miyamoto Musashi (1584-1645), was well-versed in the arts of the brush. This tanka is said to have been composed by him (to a young woman):

When it comes to love

Don't write letters

Don't write poems

For even a single penny

Watch your money carefully. ${ }^{42}$

Poetic forms tended to be short with waka, now known as tanka, forming the core form of the poetic repertoire until Matsuo Bashō elevated the hokku, the opening verse of a renga (linked verses), to what we now know as haiku, as a serious poetic form, in the latter half of the 17 th century. ${ }^{43}$ The structure of waka is simple: five lines with the syllabic structure of each line as follows: 5-7-5-7-7 giving a total of 31 syllables. Haiku have 17 syllables with the structure 5-7-5. The waka was predominantly a courtly form with a restricted range of acceptable themes, principally love and the natural world, especially the changing seasons. ${ }^{44}$ There are many wonderful books of Japanese poetry

\footnotetext{
40 McInnes (2009) The forgetting of a hero, p. 47.

41 Hiroaki Sato and Burton Watson (1981) From the country of eight islands: an anthology of Japanese poetry. Anchor Press/Doubleday, New York.

42 William Scott Wilson (2004) The lone samurai: the life of Miyamoto Musashi. Kodansha, Tokyo, p. 95.

43 Makoto Ueda (1982) Matsuo Bashō. Kodansha, Tokyo.

44 Steven D Carter (1991) Traditional Japanese poetry: an anthology. Stanford University Press, Stanford CA.
} 
- those already mentioned, to which could be added Kenneth Rexroth's One hundred poems from the Japanese. ${ }^{45}$ Daisetzu Suzuki discusses the important role Zen has in Japanese culture and how this is reflected in its poetry. ${ }^{46}$

Given the importance of poetry in Japanese cultural life, therefore, it is not surprising that some poetry was composed during the expedition to Antarctica. It is also not surprising that Shirase, the son of a Buddhist priest, also wrote poetry. Tsunabuchi quotes three haiku by Shirase, but he may have written many more. None are mentioned in Nankyoku-ki but that was intended to be a report, whereas his personal account of the expedition, Nankyoku Tanken, has not yet been translated into English.

Haiku by Shirase:

On deck

cutting my nails

this lengthy leisure

Storm over,

people are exercising

the sledge dogs

The sledge dogs

leap around the deck

wagging their tails

(translation by Amelia Fielden)

Tada was, by contrast, much more prolific and, frankly, a much better poet. Six tanka were reproduced in Kyoku: Shirase Chüi Nankyoku tankenki. ${ }^{47}$

Tanka by Tada:

As the ship sailed

Silently through the ocean

Under a clear moon,

I think the Dragon's Palace

Must be something like this

In the mild spring

Of my hometown far away

The flowers

Will be blooming

45 Kenneth Rexroth (1964) One hundred poems from the Japanese. New Directions, New York.

46 Daisetz T Suzuki (1959) Zen and Japanese culture. MJF Books, New York.

47 Tsunabuchi (1983) Kyoku: Shirase Chüi Nankyoku tankenki. 
Birds will be singing

A clear moon

A peaceful passage

Over the beautiful sea ...

Midnight and

No-one is stirring

Sky, water, water,

More sky ... despondently

I watch

The moon shining brightly

On the plains of the sea

Ah ... the plum trees

Will be in full bloom now

Around my home town -

Here no flowery hues

Colour the waves

Looking back

Looking back again

Looking back

All I'll see are mountains

And mountains of snow

(translation by Amelia Fielden)

I do not know the order in which these poems were written but there seem to be three themes in these poems. The first is wonder at the new scenes Tada is witnessing, as exemplified by the first and third tanka. The second theme is homesickness: the second and fifth tanka. The third theme is more difficult to pin down and relates to the fourth and sixth tanka. Repetition is used in both of these: 'Sky, water, water ... More sky' and 'Looking back' repeated three times. It as if he wanted to drive these scenes into his memory. Although he is despondent in the fourth tanka he is still able to enjoy the moon shining brightly. In the last tanka he realises that he will never see Antarctica again and despite the desolation of its landscapes it is a place he will never forget.

\section{Concluding remarks}

Written material relating to the Shirase expedition is scarce. Only one of the primary sources for the expedition has been translated into English. Most of the others have been out of print for decades, if not nearly a century. It is clear that 
the Shirase expedition had a rich cultural life with music, song, poetry forming an important part of its daily activities. To date only a very small fraction of that material is accessible. The publication of the translation of Nankyoku$k i$ has opened a window into the life of the expedition, revealing not only a record of amazing seamanship by Captain Nomura and the crew of the Kainan Maru, Shirase's tenaciousness in organising and leading the expedition and the courage of them all, but also insights into Japanese responses to the natural world of Antarctica and an appreciation of its beauty. Let us hope that more translations will follow.

Thanks to Shirase's determination and despite the lack of official support, Japan became a member of that 'club' of nations with a long history of Antarctic exploration. It contributed to the International Geophysical Year in Antarctica (1957-58), it was one of the original signatories of the Antarctic Treaty in 1960 and has remained engaged in Antarctica ever since. It would be fascinating to hear more about Japanese cultural life in Antarctica today.

\section{Acknowledgements}

I would like to thank the following people for their help with this project: Chet Ross, especially for sending me the illustration of the shakuhachi player on the deck of the Kainan Maru which confirmed that the Shirase expedition had a musical life; Noriko Sakai and Moko Eade, for their help with translating Japanese texts; Amelia Fielden, for translating Tada's and Shirase's poems; Pat Millar, for obtaining copies of McInnes's and Stevenson's theses; and Dr Riley Lee for helping me to learn to play Hakata-bushi. Hilary Shibata at the Scott Polar Research Institute provided invaluable feedback on an earlier draft of this paper. 
This text is taken from Antarctica: Music, sounds and cultural connections, edited by Bernadette Hince, Rupert Summerson and Arnan Wiesel, published 2015 by ANU Press, The Australian National University, Canberra, Australia. 